\title{
Goal-oriented approach to enable new business models for SME using smart products
}

\author{
Jan Hicking, Violett Zeller, Günther Schuh \\ Institute for Industrial Management, FIR at the RWTH Aachen University, Aachen, Germany \\ $\{$ Jan.Hicking, Violett.Zeller, Günther.Schuh $\} @$ fir.rwth-aachen.de
}

\begin{abstract}
The manufacturing industry has to exploit trends like "Industrie 4.0" and digitization not only to design production more efficiently, but also to create and develop new and innovative business models [1, p. 2]. New business models ensure that even SMEs are able to open up new markets and canvass new customers [2, p. 82ff.]. This means that in order to stay competitive, SMEs must transform their existing business models [3, p. 2ff.]. The creation of new business models require smart products $[4$, p. 1,5, p. 235,6 , p. 13,7, p. 2,8 , p. 322,9 , p. 7]. The required data base for new business models cannot be provided by SMEs alone, whereas smart products are able to provide a foundation, given the creation of smart data and smart services they enable [5, p. 235]. These services then expand functions and functionality of smart products and define new business models $[10,6 f$.$] . However, the development of smart products by small and medium-$ sized enterprises is still lined with obstacles [11, p. 640]. Regarding the product development process the inclusion of smart products means that new and SMEunknown domains diffuse during the process $[12$, p. 2]. Although there are many models regarding this process there appears to be a substantial lack of taking into account the competencies enabled by the implementation of digital technologies. Hence, several SME-supporting approaches fail to address the two major challenges these enterprises are faced with [13, p. 8]. This paper generally describes valid objectives containing relevant stakeholders and their allocation to the phases of the product life cycle. Within each objective the potential benefit for customers and producers is analyzed. The model given in this paper helps SMEs in defining the initiation of a product development project more precisely and hence also eases project scoping and targeting for the smartification of an already existing product.
\end{abstract}

Keywords: Smart product development, smartification

\section{$1 \quad$ Introduction}

Since the industrial revolution product development processes have constantly been making progress. While early products of mechanical engineering comprised basically on mechanical, physical parts, today's products are far more digital. With the VDI 2221 and the basic works of PAHL U. BEITZ 1977 a generic problem-solving approach was disseminated to support challenges of mechanical engineers in any type of form. The product development process was dominated by one single domain, the mechanics. 
Hereinafter new domains diffused in the development process to face disruptions during automation and other aspects [14, p. 24f., 15], for example the diffusion of informatics and electronics in mechanics created the field of mechatronics. This evolution of including more and more unknown requirements lead to several new product development process models: V-Model [15], Simultaneous Engineering [16], Mechatronics design model [17], Three-cycle Model [18], Model-based systems engineering [19], W-Model [20], Multi-Domain Matrix (MDM) [21] and more. All these models try to unite all named domains to reduce time and costs of development, while

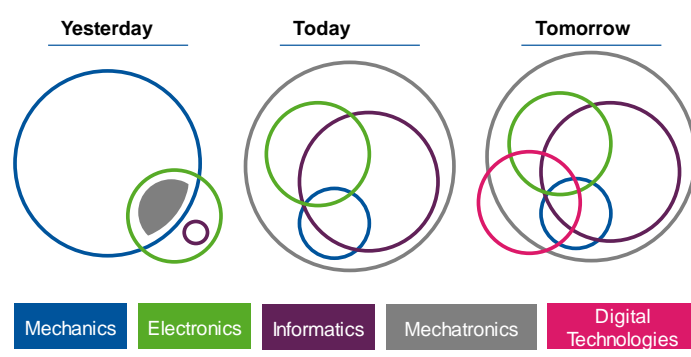

Figure 1: Domain diffuse in the product development new, relevant aspects driven by trends like digitization and "Industrie 4.0" aren't faced properly. These trends carry new requirements like product intelligence, connectivity and smarter product services [10, p. 6f., 12, p. 2].

The question for SMEs at this point in time has to be which kind of influence this evolution has on existing products. Even today, customers gravitate towards the product that has the highest scope of performance in comparison with other products of similar or identical price [12, p. 2f.]. As mentioned before, existing products must change in order to serve customer needs in the future and stay competitive, which means that SMEs have to transform their product-centered business models into new user-centered business models [10, p. 8f.]. Therefore, SMEs must develop smart products which act as the needed data collector for the creation of new business models [10, p. 6f.]. Because smart products can collect, analyze and processes data, they are the basis for smart data [10, p. 6ff.], which in turn is the basis for

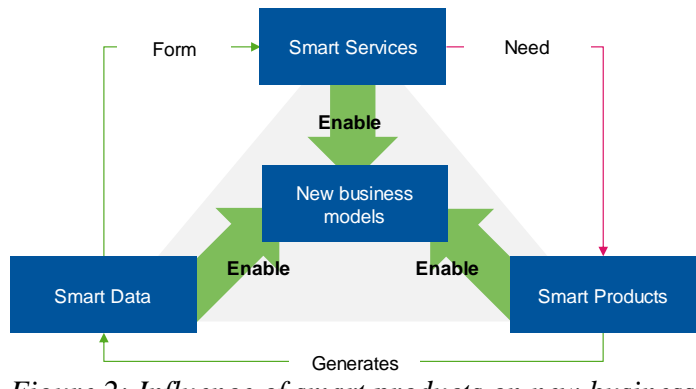

Figure 2: Influence of smart products on new business models

smart service, which ultimately enhances smart products [5, p. 235ff.]. Thus, smart products enable new business models [4, p. 1, 5, p. 235, 6, p. 18, 8, p. 322, 9, p. 7].

As already stated, certain developments in creating business models and the need for smart products bring two enormous challenges along.

The first challenge describes the development task we can define as "smartification". Many of the aforementioned development models fail to provide transformability from product to smart product. The second and most significant challenge for SMEs are ambiguous requirements due to missing target-oriented deriving methodologies.

This paper takes the first step towards dealing with these challenges by defining the term smart product properly and generally describing valid targets containing relevant stakeholders and an allocation to the phase in a product's life cycle. Taking into account 
a proper definition and valid targets for smart product, SMEs are able to plan a smartification project more precisely.

In the following chapter a definition of smart products is attempted in order to provide a general understanding of this type of product. Taking into account the frequency and the described content of the definitions, a universal definition is derived. Based on experiences of the German research project "Mittelstand 4.0-Kompetenzzenztrum Dortmund" and a literary research, generally valid targets for smart products will be presented while describing the potential benefits for SMEs and their customers.

\section{Definition: Smart Products in the manufacturing industry}

In this chapter a definition of smart products is presented. The literary analysis has shown that there exists a great amount of varying definitions of smart products. First it is shown why "smart" is the right description for those products, which are able to offer more than just a single defined function. Second it is shown what "smart products" actually means and what such a product has to be capable of.

Table 1 Different designations of "smart" products

\begin{tabular}{|c|c|c|c|c|c|c|c|c|c|c|}
\hline Source / Designation & 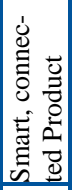 & 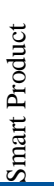 & 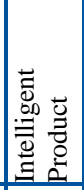 & 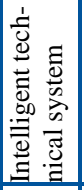 & 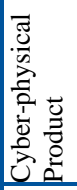 & 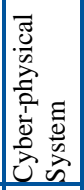 & 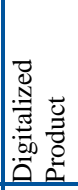 & 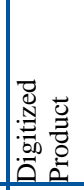 & 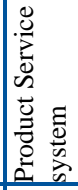 & 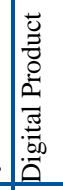 \\
\hline [22] & $\mathrm{X}$ & & & & & & & & & \\
\hline $\begin{array}{l}{[23],[24],[25],[26],[27],[28],} \\
{[29],[30]}\end{array}$ & & & $\mathrm{X}$ & & & & & & & \\
\hline$[5],[31],[32],[33],[34],[35]$ & & $\mathrm{X}$ & & & & & & & & \\
\hline [36] & & & & $\mathrm{X}$ & & & & & & \\
\hline [37], [38] & & & & & & $\mathrm{X}$ & & & & \\
\hline [39], [40] & & & & & $\mathrm{X}$ & & & & & \\
\hline$[3],[41],[42]$ & & & & & & & & & & $\mathrm{X}$ \\
\hline [43], [44], [1] & & & & & & & $\mathrm{X}$ & & & \\
\hline [45] & & & & & & & & & $\mathrm{X}$ & \\
\hline$[45],[46-49],[50]$ & & & & & & & & $\mathrm{X}$ & & \\
\hline
\end{tabular}

Following the definition of Porter and Heppelmann, smart products have physical, smart and connected components. "The result is a virtuous cycle of value improvement." [22, p. 5]. Abramovici describes smart products as cyber-physical products which are capable of condition monitoring and communication with several IT-System and are extended by product-related services [40, p. 2]. Taking Schuh's definition, we can state that smart products are based on digitized products like cyber-physical products and are extended with intelligent components [1, p. 22]. The table shows that there are many different interpretations of "smart" products. Combining these interpretations 
with the author's definitions we can conclude that the designation "smart" is a synonym for intelligent or smart, connected. The designations "cyberphysical", "digitalized"

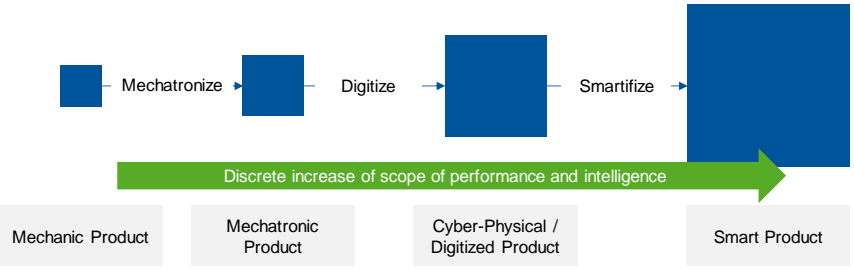

Figure 3: Definition of smart products and "digitized" are descriptions for "digitized" products. Digitized products are one of the primary stages of smart products $[1,22,40]$. Based on the definitions and designations of Schuh, Porter and Heppelmann and Abramovici, we can define smart products: smart products are based on digitized (or cyber-physical) products, they consist of physical, intelligent and connected components and are capable of a digital upgrading through internet-based services.

\section{Goal-oriented development of smart products}

This chapter presents several targets of smart products. In order to structure the targets we will use a matrix which shows, in horizontal direction, the life cycle phases of a product, segmented into "development", "production", "usage", and "recycling" [51, 52 , p. 41, 53, p. 2]. The phase "development" contains all relevant steps in the product development process, starting with product planning via requirements management through to construction and testing [53, p. 2]. The phase "production" includes all relevant steps of production and delivery. The phase "usage" contains all interaction between customer and producer in usage, from general usage of the customer via maintenance support through to after-sales support. The phase "recycling" describes all relevant steps from disposal to decomposition of the product. In addition, the matrix's vertical direction shows the strategic success factors, which includes: productivity, costs, time, quality, flexibility [54, p. 397ff.]. By analyzing the experiences of the research project "Mittelstand 4.0-Kompetenzzentrum Dortmund" and the literary research, relevant targets are assigned to product life cycle phases and to strategic success factors. The relevance of each target was validated within the interviews with project partners in the research project. The target description follows a consistent structure: each target contains its name, (1) usage potential for producers, (2) usage potential for customers and the according life cycle phase.

Following the literary analysis, we can conclude that new business models enabled by the usage of smart products are very important. When using smart products the first target is to support the transformation from a product-centered towards a user-centered business model [3, p. 142, 55, p. 32f., 56, p. 9, 57, p. 1359, 58, p. 25ff.]. Pursuing this goal means that a company is able to increase its productivity, for example a company offers the smart product as a service in the future, which means that customers pay for a service in a different manner than before. Thus, the company achieves a constant cash flow. The new business model requires a smart product which allows the offering of 
products as a service. Therefore, pursuing the target "Enable new business models" addresses a development task in correspondence with the product's life cycle phase.

1. Realize constant cash flow by offering product functions as a service

2. Only used product functions and frequency of usage is factored in

The second target describes the way field data is used to analyze the product usage and how this can be used to optimize product adjustments [56, p. 9, 59, p. 244, 60, p. 145,61, p. 101], which enables a constant improvement of the product even while it is used by the customer in the field. This is realized by analyzing condition data. If the producer adjusts the product parameters based on the analysis, the user will be able to observe a performance increase. The productivity of the product and by this, the productivity of producer and customer is increased. Taking into account that this target "Increase product performance" requires for the product to be in the field we can state that it has to be assigned to the life cycle phase "usage".

1. Increase product value and effectiveness; Increase customer satisfaction

2. Creates more individualized products which fit customer requirements better; Higher product availability

The third target "Increase product efficiency" describes how field data is used to increase the efficiency of products which leads to e.g. less downtimes [59, p. 244, 62, p. 14]. Similar to target two, this target is assigned to the phase "usage", as the product is used by customers in the field, too. The difference is that this target addresses relevant quality aspects of the product. Possible product adjustments lead to less downtimes and thus a more efficient product. Like target 2 an immediate added value for customers is achieved.

1. Increase product value and effectiveness; Increase customer satisfaction

2. Product is tailored to customer requirements; Less malfunctions reduces process costs

The fourth target "Optimize product development" describes how field data is used to support the product development process [1, p. 22, 4, 60, p. 145, 63, p. 325]. Real customer data, which describes how customers use a product is fundamental in order to develop products fitting customers more individually than before. Getting field data of a product means being able to learn about customer behavior and built up customer knowledge. This knowledge enables the creation of individualized products with lower costs.

1. Enable a learning product development; Customer experience (Customer knowledge)

2. Creates more individualized products which fit customer requirements better; Individualized customer product functions

The fifth target "Increase flexibility" describes the way smart products dissolve inflexible production systems [27, p. 6, 35, p. 11, 54, p. 401, 61, p. 101]. Flexibility in production systems allows producing a broader product range in less time with less costs.

1. Enhance competitiveness; Increase customer satisfaction

2. More flexibility in production systems due to a smart product

The sixth target "Increase product's range of function" describes how updates enable new product functions even while the product is in the field [1, p. 22, 46, 50, p. 1, 
56$, p. 9,62, p. 13,64$]$. In the past, a product's functions were limited even after the product left its producer. Smart products are able to offer more functions even when they are already in the field. Based on field data, producers are allowed to release new functions which increase the productivity of a product. Assigning this target to a product's life cycle phase, a division has to be made. One the one hand, this means that new product functions are assigned to the life cycle phase "development" for producers, for costumers on the other hand the product is assigned to the phase "usage".

1. Increase customer satisfaction; Offer customers individual functions which extend the product life cycle

2. New functions allow for the product to be used in different ways than before

The seventh target "Optimize after sales" describes how field data is used to predict product downtimes and failing components [65, p. 32]. Companies are able to plan the production of components for after-sale activities more precisely, as information about failing components predicts component lifetimes. For customers, this means that downtimes of the used product e.g. a machine tool can be prevented.

1. Production of failing components can be planned earlier, which leads to lower costs

2. Downtimes are prevented, costs regarding process interruptions are reduced

The eighth target "Optimize internal service processes" describes how field data is used to monitor the product and predict downtimes [56, p. 9]. By preemptively realizing a product failure will occur, producers are able to calculate resources for maintenance activities more precisely. Internal service processes are optimized by analyzing and incorporating field data of products. For customers, this means that downtimes of the used product e.g. a machinery tool, can be prevented.

1. Early knowledge of product failure leads to better planning of maintenance measure-ments and resources

2. Downtimes are prevented, costs regarding process interruptions are reduced

The ninth target "Service flexibility" describes how field data is used to create entirely new product-related services [57, p. 1359, 61, p. 101, 65, p. 31]. With smart products companies are able to learn more about customer behaviors, which must be analyzed during the development process to identify new customer demands. Based on these demands a company is able to develop and create entirely new services which address each customer individually.

1. Service portfolio can be developed more precisely due to knowledge of customer demands

2. More individual services are provided

The tenth target "Efficient recycling" describes how information about a product's base materials and new components, which were added during maintenance measures, is saved to support the recycling process $[9$, p. 6].

1. Transparency of all product ingredients even after delivery

2. Tracking of spare part changes in the product is not necessary anymore 
Besides interviews with SME two use cases are taken into account. First a smartification of an evacuation chair which is used in safety concepts in official buildings. Second a smartification of punching machine which is used in clothing industry. Scope of both projects was to realize the target "Optimize internal service processes" by monitoring the conditions of both products.

Regarding the assignment of each target to the phases of the product life cycle and the critical success factors we can observe that they can be divided into two groups. The first shows which targets have in common that they are using field data to create customer experience. The usage of field data influences cost and time aspects in the development and production of a product. Constantly learning about customer's means that products or services can be created which are tailored to customer requirements more efficiently than before. Unsuccessful

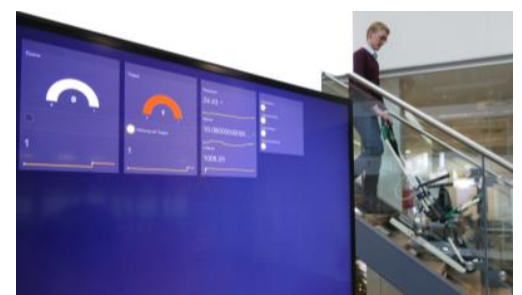

Figure 4: Smartification of an evacuation chair

product developments are minimized. Reducing costs through better planning of internal resources as well as saving time are key factors for SME's success. Building a broader understanding of customer needs, new business models can be developed and employed. Creating a product service system which covers all needs of the customer increases productivity. The second group of targets addresses an immediate increase of product value. New functions, which are updated while the product is in the field as well as new services which support the customer more individually are bound to lead to a higher customer satisfaction, higher flexibility and productivity.

Employing one or more of these targets while developing smart products, SMEs develop more goal-oriented and efficiently than before.

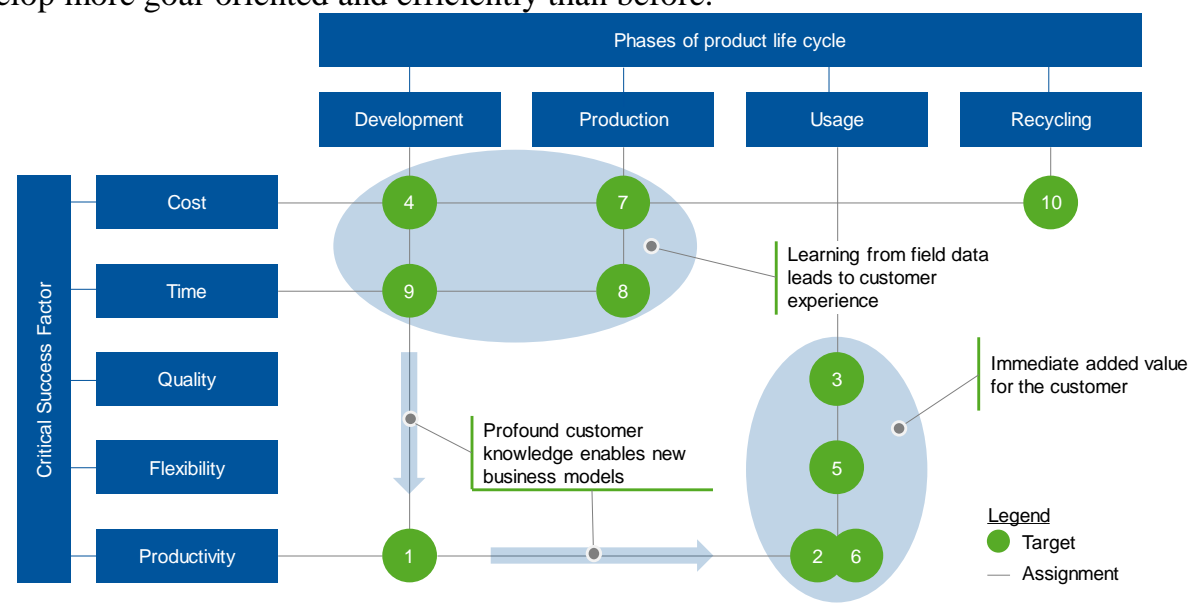

Figure 5: Assigning targets for smart products 


\section{Conclusion and further research}

This paper presented both a definition of smart products as well as several targets for smart products, as well as a number of reasons why SMEs should incorporate and develop them. Based on experiences of the German research project "Mittelstand 4.0Kompetenzzentrum Dortmund" and a literary research the targets are validated. Since SMEs are able to integrate these targets into their development processes it is important to expand this approach. A goal-oriented product development can be achieved when the targets are used to derive the relevant requirements for smart products.

\section{Acknowledgement}

This article arose during the work of the authors, within the context of the research project "Mittelstand 4.0-Kompetenzzentrum Dortmund" (project number: 01MF15001C) funded by the Federal Ministry for Economic Affairs and Energy in Germany. The authors want to thank all donors, supporter and critics.

\section{References}

[1] G. Schuh, "Industrie 4.0 in der Produktentwicklung," Aachen, Mar. 142017.

[2] H. Kagermann, IT-driven business models: Global case studies in transformation. Hoboken, N.J: John Wiley \& Sons, 2011.

[3] O. Gassmann, K. Frankenberger, and M. Csik, Geschäftsmodelle entwickeln: 55 innovative Konzepte mit dem St. Galler Business Model Navigator, 2nd ed. München: Hanser, 2017, DOI: 10.3139/9783446452848.

[4] S. Michel, Mit Digitalisierung Produkte und Prozesse optimieren. Digitale Produktentwicklung. [Online] Available: http://www.maschinenmarkt.vogel.de/mit-digitalisierung-produkte-und-prozesse-optimieren-a-545414/. Accessed on: Jun. 042017.

[5] H. Kagermann, "Chancen von Industrie 4.0 nutzen," in Springer Reference Technik, Handbuch Industrie 4.0 Bd. 4: Allgemeine Grundlagen, B. Vogel-Heuser, T. Bauernhansl, and M. ten Hompel, Eds., 2nd ed., Berlin, Heidelberg, s.l.: Springer Berlin Heidelberg, 2017, pp. 235-246, DOI: 10.1007/978-3-66253254-6_12.

[6] V. Bellersheim, "Digitale Geschäftsmodelle und Trends im Maschinenbau," Vortrag auf dem Jahrestreffen des Europäischen Verbandes der Werkzeugmaschinenhersteller (CECIMO), Nov. 2016.

[7] M. Röglinger and N. Urbach, "Digitale Geschäftsmodelle im Internet der Dinge," Diskussionspapier, Bayreuth, Geschäftsmodelle in der digitalen Welt, Aug. 2016. [Online] Available: https://fim-rc.de/Paperbibliothek/Veroeffentlicht/589/wi-589.pdf.

[8] M. Wildbihler, B. Stelzer, E. Schiebel, and L. Brecht, "Internet der Dinge," in Schwerpunkt, Digitale Transformation von Geschäftsmodellen: Grundlagen, Instrumente und Best Practices, D. Schallmo, A. Rusnjak, J. Anzengruber, T. 
Werani, and M. Jünger, Eds., Wiesbaden: Springer Gabler, 2017, pp. 311-331, DOI: $10.1007 / 978-3-658-12388-8 \_12$.

[9] M. Barbian et al., "Digitale Chancen und Bedrohungen - Geschäftsmodelle für Industrie 4.0," Statusreport, o.O., May. 2016.

[10] K. Lauenroth, F. Schreiber, and F. Schreiber, Maschinen- und Anlagenbau im digitalen Zeitalter: Requirements Engineering als systematische Gestaltungskompetenz für die Fertigungsindustrie Industrie 4.0, 1st ed. s.1.: Beuth Verlag $\mathrm{GmbH}, 2016$.

[11] A. Issa, D. Lucke, and T. Bauernhansl, "Mobilizing SMEs Towards Industrie 4.0-enabled Smart Products," in Volume 63, Manufacturing Systems 4.0 - Proceedings of the 50th CIRP Conference on Manufacturing Systems, M. M. Tseng, H.-Y. Tsai, and Y. Wang, Eds., o.O.: Elsevier, 2017, pp. 670-674, DOI: 10.1016/j.procir.2017.03.346.

[12] O. Brauckmann, Smart Production: Wertschöpfung durch Geschäftsmodelle. Berlin: Springer Vieweg, 2015, DOI: 10.1007/978-3-662-45302-5.

[13] A. A. Gonzales, K. Becker, C.-H. Cheng, V. Döricht, and M. Duchon, Digitale Transformation: Wie Informations- und Kommunikationstechnologie etablierte Branchen grundlegend verändern. München: fortiss GmbH, 2016.

[14] C. Kühnl, "Software gibt den Takt vor," Mechatronic \& Fertigung, 2010, pp. 20-21, 2010.

[15] Design methodology for mechatronic systems, 2206, 2004.

[16] H.-J. Bullinger, J. Warschat, and A. Bading, Eds., Forschungs- und Entwicklungsmanagement: Simultaneous Engineering, Projektmanagement, Produktplanung, Rapid Product Development. Stuttgart: Teubner, 1997, DOI: 10.1007/978-3-663-05946-2.

[17] C. Hollauer et al., "Adaptable Mechatronic Engineering Design Processes: Process Reference Model and Methodology," in Smart Innovation, Systems and Technologies, v.65, Research into Design for Communities, Volume 1: Proceedings of ICoRD 2017, A. Chakrabarti, Ed., Singapore: Springer Singapore, 2017, pp. 597-607, DOI: 10.1007/978-981-10-3518-0_52.

[18] J. Gausemeier, P. Ebbesmeyer, and F. Kallmeyer, Produktinnovation: Strategische Planung und Entwicklung der Produkte von morgen. München [u.a.]: Hanser, 2001.

[19] G. Beier, U. Rothenburg, R. Woll, and R. Stark, "Modellbasiertes Systems Engineering: Durchgängige Entwicklung mit erlebbaren Prototypen," Digital Engineering, 2012, pp. 14-17, 2012, https://www.digital-engineering-magazin.de/sites/default/files/magazine-pdf/de_2012_03_inhalt_farm.pdf.

[20] R. Nattermann and R. Anderl, "Approach for a Data-Managmenet-System and a Proceeding-Model for the Development of Adaptronic Systems," in Volume 3: Design and Manufacturing, Parts $A$ and B, Vancouver, British Columbia, Canada, 2010, pp. 379-387, DOI: 10.1115/IMECE2010-37828.

[21] J. Ponn and U. Lindemann, Konzeptentwicklung und Gestaltung technischer Produkte: Systematisch von Anforderungen zu Konzepten und Gestaltlösungen, 2nd ed. Heidelberg [Germany]: Springer, 2011, DOI: 10.1007/978-3-64220580-4. 
[22] M. E. Porter and J. E. Heppelmann, "How Smart, Conntected Products Are Transforming Competition: Spotlight on managing the internet of things," Harvard Business Review, November 2014, pp. 64-88, 2014.

[23] R. Anderl, A. Picard, and K. Albrecht, "Smart Engineering for Smart Products," in Lecture notes in production engineering, Smart product engineering: Proceedings of the 23rd CIRP Design Conference, Bochum, Germany, March 11th - 13th, 2013, M. Abramovici and R. Stark, Eds., Berlin: Springer, 2013, pp. 110, DOI: 10.1007/978-3-642-30817-8_1.

[24] Mario Hermann, Tobias Pentek, and Boris Otto, "Design Principles for Industrie 4.0 Scenarios: A Literature Review," 2015, DOI: 10.13140/RG.2.2.29269.22248.

[25] M. Weyrich, "Industrie 4.0 und intelligente Produkte: Wie Automatisierungsund Softwaresysteme der nächsten Generation die Produktentwicklung und Produktion verändern,” München, Jun. 172015.

[26] R. Anderl, "Industrie 4.0 - Advanced Engineering of Smart Products and Smart Production," 2014, DOI: 10.13140/2.1.1039.4406.

[27] J. Schlick, P. Stephan, M. Loskyll, and D. Lappe, "Industrie 4.0 in der praktischen Anwendung," in Springer Reference Technik, Handbuch Industrie 4.0: Bd. 2 : Automatisierung, B. Vogel-Heuser, T. Bauernhansl, and M. ten Hompel, Eds., 2nd ed., Berlin: Springer Vieweg, 2017, pp. 3-29, DOI: 10.1007/978-3662-53248-5_46.

[28] B. Vogel-Heuser, T. Bauernhansl, and M. ten Hompel, Eds., Handbuch Industrie 4.0: Bd. 2 : Automatisierung, 2nd ed. Berlin: Springer Vieweg, 2017, DOI: 10.1007/978-3-662-53248-5.

[29] D. McFarlane, V. Giannikas, A. C. Y. Wong, and M. Harrison, "Intelligent Products in the Supply Chain - 10 Years on," in Studies in Computational Intelligence, Service Orientation in Holonic and Multi Agent Manufacturing and Robotics, T. Borangiu, A. Thomas, and D. Trentesaux, Eds., Berlin, Heidelberg: Springer Berlin Heidelberg, 2013, pp. 103-117, DOI: 10.1007/978-3-64235852-4_7.

[30] D. Kiritsis, "Closed-loop PLM for intelligent products in the era of the Internet of things," Computer-Aided Design, vol. 43, no. 5, pp. 479-501, 2011, DOI: 10.1016/j.cad.2010.03.002.

[31] B. Vogel-Heuser, "Preparing for the 4.0 Future: Industry strategies in anticipation of 4.0," Munich [u.a.], Aug. 212015.

[32] S. Janzen and W. Maass, "Smart Product Descprition Object (SPDO)," in Frontiers in artificial intelligence and applications, v. 183, Formal ontology in information systems: Proceedings of the Fifth International Conference (FOIS 2008), C. Eschenbach and M. Gruninger, Eds., Amsterdam, Netherlands, Fairfax, VA: IOS Press, 2008, pp. 25-30.

[33] H. Meier and E. Uhlmann, Eds., Integrierte Industrielle Sach- und Dienstleistungen: Vermarktung, Entwicklung und Erbringung hybrider Leistungsbündel. Berlin, Heidelberg: Springer Berlin Heidelberg, 2012, DOI: 10.1007/978-3-642-25269-3. 
[34] P. Seidenschwang, "Smart Products Engineering," White Paper, Eschborn, 2013.

[35] H.-G. Scheibe, "Smart Products: Neue Spielregeln für die Industrie," in ROI Dialog, ROI Management Consulting AG, Ed., 2016, pp. 10-11.

[36] it's OWL, "So intelligent können Produkte sein," Paderborn, 2015.

[37] T. Krause et al., IT-Plattformen für das Internet der Dinge (IoT): Basis Intelligenter Produkte und Services. Stuttgart: Fraunhofer Verlag, 2017.

[38] S. Sapatnekar, Ed., Proceedings of the 47th Design Automation Conference on $D A C$ '10. New York, New York, USA: ACM Press, 2010.

[39] U. Sendler, Ed., Industrie 4.0 grenzenlos. Berlin, Heidelberg: Springer Berlin Heidelberg; Springer Vieweg, 2016, DOI: 10.1007/978-3-662-48278-0.

[40] M. Abramovici, "Smart Products," in CIRP Encyclopedia of Production Engineering, The International Academy for Produ, L. Laperrière, and G. Reinhart, Eds., Berlin, Heidelberg: Springer Berlin Heidelberg, 2014, pp. 1-5, DOI: 10.1007/978-3-642-35950-7_16785-1.

[41] P. Samulat, Die Digitalisierung der Welt: Wie das Industrielle Internet der Dinge aus Produkten Services macht. Wiesbaden: Springer Fachmedien Wiesbaden, 2017, DOI: 10.1007/978-3-658-15511-7.

[42] E. Westkämper, D. Spath, C. Constantinescu, and J. Lentes, Eds., Digitale Produktion. Berlin, Heidelberg, s.l.: Springer Berlin Heidelberg, 2013, DOI: $10.1007 / 978-3-642-20259-9$.

[43] S. Janata, "Leitfaden Digitalisierung: Strategien, Technologien und Ökosysteme," Kassel, 2016.

[44] R. Kreutzer and K.-H. Land, Digitaler Darwinismus: Der stille Angriff auf Ihr Geschäftsmodell und Ihre Marke; das Think!Book, 2nd ed. Wiesbaden: Springer Gabler, 2016, DOI: 10.1007/3-211-27349-2_42.

[45] M. M. Herterich and M. Mikusz, "Looking for a Few Good Concepts and Theories for Digitized Artifacts and Digital Innovation in a Material World," in 37th International Conference on Information Systems (ICIS 2016): Dublin, Ireland, 11-14 December 2016, Association for Information Systems (AIS), Ed., Red Hook (USA): Curran Associates Inc, 2017, pp. 750-771.

[46] Y. Yoo, O. Henfridsson, and K. Lyytinen, "Research Commentary — The New Organizing Logic of Digital Innovation: An Agenda for Information Systems Research," Information Systems Research, vol. 21, no. 4, pp. 724-735, 2010, DOI: $10.1287 /$ isre.1100.0322.

[47] Y. Yoo, "The Tables Have Turned: How Can the Information Systems Field Contribue to Technology and Innovation Management Research?, JAIS, vol. 14, no. 5, pp. 227-236, 2013.

[48] Y. Yoo, R. J. Boland, K. Lyytinen, and A. Majchrzak, "Organizing for Innovation in the Digitized World," Organization Science, vol. 23, no. 5, pp. 13981408, 2012, DOI: $10.1287 /$ orsc. 1120.0771.

[49] Y. Yoo, "Computing In Everday Life: A Call for Research on Experiental Computing," MIS QUARTERLY, vol. 34, no. 2, pp. 213-231, Jun. 2010, DOI: $10.2307 / 20721425$. 
[50] A. Novales, M. Mocker, and D. Simonovich, "IT-enriched "Digitized" Products: Building Blocks and Challenges," Paper, AMICS, San Diego (USA), 2016. Accessed on: Dec. 172017.

[51] T. Hill, Production/operations management. Englewood Cliffs, NJ: PHI Prentice-Hall International, 1983.

[52] J. Feldhusen and B. Gebhardt, Product Lifecycle Management für die Praxis: Ein Leitfaden zur modularen Einführung, Umsetzung und Anwendung. Berlin, Heidelberg: Springer-Verlag Berlin Heidelberg, 2008, DOI: 10.1007/978-3-54034009-6.

[53] M. Eigner and R. Stelzer, Product Lifecycle Management: Ein Leitfaden für Product Development und Life Cycle Management, 2nd ed. Dordrecht: Springer, 2013, DOI: 10.1007/b93672.

[54] G. Schuh, Ed., Produktionsplanung und -steuerung: Grundlagen, Gestaltung Und Konzepte. Dordrecht: Springer, 2006, DOI: 10.1007/3-540-33855-1.

[55] H. Kagermann et al., "Smart Service Welt: Umsetzungsempfehlungen für das Zukunftsprojekt Internetbasierte Dienste für die Wirtschaft," Berlin, Mar. 2014.

[56] M. M. Herterich, A. Eck, and F. Uebernickel, "EXPLORING HOW DIGITIZED PRODUCTS ENABLE INDUSTRIAL SERVICE INNOVATION - AN AFFORDANCE PERSPECTIVE," 24. European Conference on Information Systems (ECIS), İstanbul,Turkey, 2016 4, Istanbul (Türkei), Research Papers 156, 2016. [Online] Available: http://aisel.aisnet.org/ecis2016_rp/156. Accessed on: Dec. 172017.

[57] K. Santos, E. Loures, F. Piechnicki, and O. Canciglieri, "Opportunities Assessment of Product Development Process in Industry 4.0," Procedia Manufacturing, vol. 11, pp. 1358-1365, 2017, DOI: 10.1016/j.promfg.2017.07.265.

[58] D. Schallmo and A. Rusnjak, "Roadmap zur Digitalen Transformation von Geschäftsmodellen," in Schwerpunkt, Digitale Transformation von Geschäftsmodellen: Grundlagen, Instrumente und Best Practices, D. Schallmo, A. Rusnjak, J. Anzengruber, T. Werani, and M. Jünger, Eds., Wiesbaden: Springer Gabler, 2017, pp. 2-28, DOI: 10.1007/978-3-658-12388-8_1.

[59] M. J. Cronin, Smart products, smarter services: Strategies for embedded control. Cambridge: Cambridge Univ. Press, 2010.

[60] E. Schaupp, E. Abele, and J. Metternich, "Potentials of Digitalization in Tool Management," Procedia CIRP, vol. 63, pp. 144-149, 2017, DOI: 10.1016/j.procir.2017.03.172.

[61] A. Demont and D. Paulus-Rohmer, "Industrie 4.0-Geschäftsmodelle systematisch entwickeln," in Schwerpunkt, Digitale Transformation von Geschäftsmodellen: Grundlagen, Instrumente und Best Practices, D. Schallmo, A. Rusnjak, J. Anzengruber, T. Werani, and M. Jünger, Eds., Wiesbaden: Springer Gabler, 2017, pp. 97-125, DOI: 10.1007/978-3-658-12388-8_4.

[62] G. G. Meyer, K. Främling, and J. Holmström, "Intelligent Products: A survey," Computers in Industry, vol. 60, no. 3, pp. 137-148, 2009,

DOI: 10.1016/j.compind.2008.12.005. 
[63] M. M. Herterich, F. Uebernickel, and W. Brenner, "The Impact of Cyber-physical Systems on Industrial Services in Manufacturing," Procedia CIRP, vol. 30, pp. 323-328, 2015, DOI: 10.1016/j.procir.2015.02.110.

[64] M. E. Porter and J. E. Heppelmann, "How Smart, Connected Products Are Transforming Companies,” Harvard Business Review, Oktober 2015, 96-112, $114,2015$.

[65] G. Schuh and R. Kreutzer, "Utility Potentials of Cyber-Physical Systems' Field Data," in 14, vol. 1, IJERD - International Journal of Engineering Research and Development, H. U. Akay, M. P. Bendsoe, F. Brezzi, and M. D. Castellano, Eds., o.O.: IJERD, 2018, pp. 24-35. 